Wirtschaftswissenschaftliches Zentrum (WWZ) der Universität Basel

$\mathrm{WW} \mid \mathrm{Z}$

January 2012

\title{
Does Culture Affect Corporate Governance?
}


The Authors:

Prof. Dr. Pascal Gantenbein

Head of the Henri B. Meier Department of

Financial Management

University of Basel

Peter Merian-Weg 6

CH - 4002 Basel

phone: +41(0)61 2672459

pascal.gantenbein@unibas.ch

\section{Dr. Christophe Volonté, Assistant}

Faculty of Business and Economics

University of Basel

Peter Merian-Weg 6

CH - 4002 Basel

phone: +41(0)612672462

christophe.volonte@unibas.ch

A publication of the Center of Business and Economics (WWZ), University of Basel.

(C) The authors. Reproduction for other purposes than the personal use needs the permission of the author. 


\title{
Does Culture Affect Corporate Governance?
}

\author{
Pascal Gantenbein* Christophe Volonté ${ }^{*}$ \\ University of Basel \\ Faculty of Business and Economics \\ Working Paper \\ January 11, 2012
}

\begin{abstract}
The legal environment is one important determinant of corporate governance. However, within legal families, also cultural differences can explain the level of corporate governance to some extent. We analyze this relationship for the case of Switzerland. Swiss firms are mainly located in two cultural areas, the German and French speaking parts of Switzerland. Swiss federal law is equal in both regions which allows us to investigate the effect of cultural differences on corporate governance. Although we only find few differences, we observe that board composition is significantly driven by language-related factors: French-speaking directors are prevalent in Swiss French boards and German-speaking directors in Swiss German boards. More importantly, however, boards of these two parts of Switzerland are more likely to be structured as in their respective neighboring countries. Furthermore, in the French part, transfer restrictions of shares are more common.
\end{abstract}

JEL-Classification: G30, G32, G34, G38, Z10

Keywords: Corporate governance, Culture, Law, Board of directors, Ownership structure

*Prof. Dr. Pascal Gantenbein is head of the Henri B. Meier Department of Financial Management, University of Basel, Switzerland.

${ }^{\dagger}$ Christophe Volonté is assistant at the Henri B. Meier Department of Financial Management, University of Basel, Switzerland.

${ }^{\ddagger}$ Corresponding author. Christophe Volonté, Faculty of Business and Economics, Peter MerianWeg 6, CH-4002 Basel, Switzerland, Tel: +41-61-267-24-62; fax: +41-61-267-24-63; e-mail: christophe.volonte@unibas.ch. 
Investors are legally protected from severe misconduct by managers (e.g., by the duty of care and duty of loyalty). In addition, corporate governance reduces the scope of further wrong managerial behavior. Hence, the legal environment is one important determinant of practices in corporate governance. In a series of papers, La Porta et al. $(1998,2000)$ show that investor protection differs significantly among countries. Common law countries are typically associated with a higher level of investor protection than civil law countries. Lower investor protection is related to a higher ownership concentration and weaker financial markets. Some shareholders may also protect themselves by accumulating significant voting rights and monitor the management more strictly by themselves. However, these large shareholders may extract private benefits of control if investor protection is low. ${ }^{1}$ In such situations, the conflict between controlling and minority shareholders may be more severe than the classical agency conflict between managers and shareholders. The empirical evidence of La Porta et al. (2000) also suggests that the legal system has an influential impact on corporate governance: legal families are differently capable to protect investors from managers and/or other shareholders.

However, academic researchers debate whether the legal system is the one and only determinant of corporate governance. Bebchuk and Roe (1999) allege that the initial ownership structure in an economy defines further developments in corporate governance. They argue that path dependencies may explain why private benefits of control (and ownership concentration) are still higher in some countries than in others. Aguilera and Jackson (2003) assume that countries adopt best practices of corporate governance that fit their specific institutional environment. The studies suggest that historical circumstances, too, influence corporate governance.

Thus, the affiliation to a legal family (e.g., civil or common law) and the legal enforcement may not be the only determinant of corporate governance or the development of the financial markets. For instance, Djankov et al. (2008) suppose that the strong financial market in Switzerland is a result of factors they probably missed, because the standard of Swiss investor protection is not especially high in terms of international standards.

A country's culture may be another factor that influences corporate governance. Indeed, Dyck and Zingales (2004) show that the prevalence and level of private benefits of control (used as a direct proxy for investor protection) is also influenced by cultural norms within a country and not solely a result of low investor protection. Legal mechanisms (e.g., accounting standards), but also extra-legal mechanisms such as pressure coming from the public opinion curb the level of private benefits. Shareholders fear negative public opinion and reputation costs if the media uncover bad behavior. They conclude that apart from the legal system, cultural aspects influence the way how investors are

\footnotetext{
${ }^{1}$ Private benefits of control can arise in addition to shared benefits of control (benefits for controlling and non-controlling shareholders, e.g., stock price increases) for the controlling shareholder (e.g., consumption of perquisites or prestige) (Dyck and Zingales, 2004).
} 
being protected. Licht et al. (2005) find further empirical evidence that culture has a significant impact on corporate governance-related law. ${ }^{2}$ Hence, the link between ownership concentration, private benefits of control, corporate governance, and the legal system is not undisputed. Factors different from the affiliation to a certain legal family do also influence the firm's governance. Cultural differences within legal families among countries and within countries hence do potentially drive the structure of corporate governance.

We examine the impact of cultural differences - in contrast to the legal system on corporate governance. Switzerland offers an interesting research opportunity, because Swiss firms are located in two main cultural areas: German-speaking and Frenchspeaking Switzerland. These two areas are culturally influenced by their closest neighbors: France and Germany which are two important economies in Continental Europe that have distinct cultural peculiarities. In contrast to the United States where state law can significantly differ, the federal law fully defines corporate law in Switzerland. ${ }^{3}$ Hence, the legal system is the same in both regions and, in turn, differences in corporate governance may be explained by culture. ${ }^{4}$ Therefore, our study compares corporate governance of Swiss French and Swiss German firms. The analysis investigates the differences in ownership structures, takeover defenses, boards of directors as well as characteristics of directors, chief executive officers (CEOs), and firms. Significant differences in corporate governance suggest that culture might play a role.

\section{Literature Review}

The corporate landscape of Switzerland is roughly divided into the French and the German part of Switzerland. ${ }^{5}$ Because of strong cultural influences from their neighbors, it is important to discuss shortly the systems of corporate governance of France and Germany.

The legal systems of France and Germany are based on civil law. La Porta et al. (2000) show that investor protection is weaker in countries with civil law of French origin and

\footnotetext{
${ }^{2}$ Their "corporate governance law" is based on the "anti-director rights index" and the "creditor rights index" applied by La Porta et al. (2000).

${ }^{3}$ Cantonal law differs in some cases (e.g., tax law) and law enforcement is usually in the responsibility of the 26 cantons.

${ }^{4}$ In a similar approach, Bozec et al. (2008) and Boubraki et al. (2011) show that Canadian firms in the French-speaking province of Québec have a higher ownership concentration than firms in the other (English-speaking) provinces. However, Québec firms, unlike Swiss firms, can choose to incorporate under the Canadian federal law (based on common law) or the Québec provincial law (based on civil law). They reveal that the incorporation under the civil-law regime is significantly positively related to the ownership concentration. Therefore, they confirm that the legal system is an important determinant of the ownership concentration.

${ }^{5}$ Only very few public companies are located in the other two cultural areas of Switzerland: Italian and Rhaeto-Romansch.
} 
stronger in common-law countries, e.g., Anglo-Saxon countries. The German civil law system lies in between. Similarly, the private benefits of control are higher in legal systems of French origin than in Germanic legal systems (see Dyck and Zingales, 2004). ${ }^{6}$ Switzerland's legal system belongs to the German-type of civil law.

The corporate governance in each country is not only aimed at meeting the interests of shareholders, but also those of other stakeholders (e.g., debtholders, employees or government). In France, state interference in the economy is not uncommon ("dirigism"). By contrast, in Germany, there tend to be close ties to the banks which is referred to as the "Hausbankensystem" (La Porta et al., 2000).

The ownership structure in both countries is relatively concentrated compared to Anglo-Saxon countries where ownership is usually dispersed: 65 percent of all listed firms (70 percent of all listed non-financial firms) in France and Germany are controlled by families. ${ }^{7}$

The market for corporate control is not very important in Germany and France. This may be linked to these societies' attitudes towards hostile takeovers. As an example, the former president of the Social Democratic Party in Germany, Franz Müntefering, has called activist investors "Heuschrecken" (grasshoppers) that erode the industrial landscape (Brost, 2005). In this way, he backed the target firm's management and agitated against corporate restructuring. In France, the state has also directly intervened in some cases of takeovers. For instance, preemptive media pressure accompanied a potential takeover of Danone by Pepsi. Also, Suez and GDF were merged into a French energy giant to make a takeover more expensive. And the state (unsuccessfully) intervened into the Arcelor-Mittal deal (see The Economist, 2006).

The board of directors has distinct features. The French board of directors can be structured as being either one-tiered or two-tiered. The one-tiered board is often controlled by the chairman and CEO in one person. Two-tiered boards consist of a supervisory board which is strictly separated from the management board (see Hopt and Leyens, 2004). ${ }^{8}$ In Germany, the two-tier board structure is mandatory. ${ }^{9}$ Hence, the monitoring function of the German-style board is important. The Swiss corporate law, as in France, does not mandate a specific board structure.

In general, the Swiss corporate governance is closer to the Anglo-Saxon system. As argued in literature, the main objective of most firms is to increase the shareholders' wealth (Wymeersch, 1998). Furthermore, the financial market in Switzerland is more

\footnotetext{
${ }^{6}$ However, the mix of countries in the respective legal system tends to influence the private benefits of control.

${ }^{7}$ Control is defined as having 20 percent or more of voting rights (see Faccio and Lang, 2002).

${ }^{8}$ In France, one-tiered boards are called "conseils d'administration" and are commonly controlled by the "président-directeur-générale" (or short: "PDG"). Two-tier boards consist of the "conseil de surveillance" and the "directoire".

${ }^{9}$ In Germany, the supervisory board is called "Aufsichtsrat" and the management board is denoted "Vorstand".
} 
important with respect to the ratio of the total market value of equity to the gross domestic product than in France and Germany (4.01, 1.30, 0.72, respectively). ${ }^{10}$ As another feature, Swiss firms do rely on large-scale exports and quite often produce worldwide. As a result, the corporate governance of both Swiss German and Swiss French firms may be adopted to international standards. Anyhow, specific differences caused by cultural factors may still persist.

\section{Empirical Analysis}

The empirical analyses examines differences in the corporate governance between firms incorporated in the German- and the French-speaking part of Switzerland. The sample consists of 163 firms of which 136 (83 percent) are located in German-speaking Switzerland, while 27 firms (17 percent) are located in the Swiss French area. We exclude regulated industries (utilities and banks) as well as financial services. The former tend to be influenced by other factors than culture and the latter exhibit an incomparable corporate structure. In addition, the four firms from the Italian part (of which two are utilities) are excluded from the analysis, as well.

The significances of differences are measured using t-tests for the equality of means and Wilcoxon rank sum-tests for the equality of medians. The medians are integrated, because otherwise the results may be influenced by outliers.

\subsection{Ownership Structure}

The ownership structure of an economy is an important factor in corporate governance and shapes the agency relationships within the firms. While in Anglo-Saxon countries corporations are mostly widely held, in the rest of the world, including Switzerland, many firms are controlled by one important shareholder, e.g, a family. Such blockholders own significant voting rights exceeding the disclosure threshold of three percent. We analyze the overall ownership structure, the existence of shareholder agreements, the type of the largest investors, and the nationality of investors. The origin of shareholders may be important since they may have specific investment preferences. For instance, U.S. institutional investors may invest in firms with high standards of U.S.-style corporate governance, and German or French shareholders may prefer to invest in firms that are culturally close.

Table I indicates that strong differences in the ownership structure do not exist with both, t-test and Wilcoxon rank sum-test, being significant. However, as a sole finding, the largest shareholder in Swiss German firms more often is an individual. Hence, the

\footnotetext{
${ }^{10}$ Source: "CIA - The World Factbook"; https://www.cia.gov/library/publications/ the-world-factbook/.
} 
results suggest that the ownership structure emerged rather from legal or historical conditions than from cultural differences.

Table I: The table presents comparisons of ownership structures between Swiss German and Swiss French firms. The equality of medians is tested using a Wilcoxon rank sum-test with continuity correction and the equality of means is tested using a Welch Two Sample t-test. Significance at the 1 percent, 5 percent, and 10 percent levels is indicated by ***, **, and *, respectively. "Yes" is denoted y and "no" is denoted n.

\begin{tabular}{|c|c|c|c|c|c|c|}
\hline & Sample & \multicolumn{2}{|c|}{ Swiss German } & \multicolumn{2}{|c|}{ Swiss French } & \\
\hline Observations & 163 & \multicolumn{2}{|c|}{136} & \multicolumn{2}{|c|}{27} & \\
\hline in $\%$ & 100 & \multicolumn{2}{|c|}{83} & \multicolumn{2}{|c|}{17} & \\
\hline & Mean & Mean & Median & Mean & Median & $\begin{array}{c}\text { t-test/ } \\
\text { (Wilcoxon-test) }\end{array}$ \\
\hline \multicolumn{7}{|l|}{ Panel A: Ownership Structure } \\
\hline Number of blockholders (count) & 3.3 & 3.2 & 3.0 & 3.4 & 3.0 & \\
\hline Cumulated ownership (in \%) & 46.2 & 45.6 & 46.1 & 49.6 & 51.6 & \\
\hline Shareholder agreement $(\mathrm{y}=1, \mathrm{n}=0)($ in $\%)$ & 16.0 & 15.4 & - & 18.5 & - & \\
\hline Majority shareholder $(\mathrm{y}=1, \mathrm{n}=0)($ in $\%)$ & 29.5 & 27.2 & - & 40.7 & - & \\
\hline \multicolumn{7}{|l|}{ Panel B: Largest Shareholders (in \%) } \\
\hline Largest shareholder ownership & 31.9 & 31.1 & 24.7 & 35.4 & 29.2 & \\
\hline Type of the largest shareholder: & & & & & & \\
\hline - family $(\mathrm{y}=1, \mathrm{n}=0)$ & 24.5 & 22.1 & - & 37.0 & - & \\
\hline - individual $(\mathrm{y}=1, \mathrm{n}=0)$ & 29.5 & 32.4 & - & 14.8 & - & $* * /(*)$ \\
\hline - state $(y=1, n=0)$ & 2.5 & 2.9 & - & 0.0 & - & $* * /(-)$ \\
\hline - industry firm $(\mathrm{y}=1, \mathrm{n}=0)$ & 14.7 & 12.5 & - & 25.9 & - & $-/(*)$ \\
\hline Second largest shareholder ownership & 6.7 & 6.7 & 5.3 & 6.8 & 6.7 & \\
\hline \multicolumn{7}{|l|}{ Panel C: Nationality of Shareholders (in \%) } \\
\hline Local investors & 32.4 & 31.9 & 26.0 & 34.7 & 29.2 & \\
\hline U.S. institutional shareholders & 2.2 & 2.4 & 0.0 & 1 & 0.0 & $* * /(-)$ \\
\hline German shareholders & 2.9 & 3.2 & 0.0 & 1.8 & 0.0 & \\
\hline French shareholders & 0.1 & 0.0 & 0.0 & 1.5 & 0.0 & $-/(* * *)$ \\
\hline
\end{tabular}

\subsection{Takeover Defenses}

The market for corporate control is a particularly important governance mechanism in countries with a strong financial market, namely the United States. However, hostile takeovers are frequently accompanied by critics of the media and politicians. Thus, cultural norms are important in explaining to what extent the use of devices that lower the probability of a successful hostile takeover (or any forced corporate restructuring) are accepted by society. We include three takeover defenses that tend to decouple the voting from the cash flow rights: multiple classes of shares, transfer restrictions of (registered) shares ("Vinkulierung"), and voting restrictions.

Multiple classes of shares typically allow one group of shareholders to get control over the firm, e.g., by issuing non-voting shares. In the case of a transfer restriction, the board of the firm can decide whether a shareholder is entered into the company share register 
or not and with how many shares. Only registered shareholders, in the case of registered shares ("Namenaktien"), do have voting rights (see Dubs and Wieser, 2009). Additionally, the articles of incorporation may provide voting rights restrictions (e.g., at 5 percent) for registered and bearer shares. ${ }^{11}$ The takeover defenses ("clauses on changes of control") include measures such as severance payments (see Directive on Information relating to Corporate Governance, 7.2., SIX Exchange, 2008). As another important takeover defense discussed in the Anglo-Saxon corporate governance literature, staggered boards are included in the analysis. The staggered (or classified) board prevents a board majority (and the control over the firm) from being replaced at only one general assembly since typically only one third of the board is replaced at once. However, in Switzerland, shareholders are usually able to dismiss directors at any shareholders' meeting. Finally, firms can opt out of the obligation that the acquirer has to make a tender offer. In this case, minority shareholders are not able to tender their shares if they do not want to stay invested when the control structure changes significantly.

Table II shows that also the differences in the prevalence of takeover defenses are rare. However, Swiss French firms are more likely to be protected against hostile takeovers by transfer restrictions of shares, while Swiss German firms installed staggered (or classified) boards against unwelcome investors. This result suggests also that registered shares (French: "actions nominatives") are more frequently issued by Swiss French companies.

Table II: The table presents comparisons of takeover defenses between Swiss German and Swiss French firms. The equality of medians is tested using a Wilcoxon rank sum-test with continuity correction and the equality of means is tested using a Welch Two Sample t-test. Significance at the 1 percent, 5 percent, and 10 percent levels is indicated by ***, **, and *, respectively. "Yes" is denoted y and "no" is denoted n.

\begin{tabular}{lcccccc}
\hline & Sample & Swiss German & \multicolumn{2}{c}{ Swiss French } & \\
\hline Observations & 163 & 136 & & 27 & \\
in \% & 100 & 83 & & 17 & \\
\hline & Mean & Mean & Median & Mean & Median & (Wilcoxon-test) \\
\hline Takeover defenses ( $\mathrm{y}=1, \mathrm{n}=0$ ) (in \%) & 30.7 & 30.2 & - & 33.3 & - & \\
Multiple classes of equity (y=1,n=0) (in \%) & 19.6 & 17.7 & - & 29.6 & - & \\
Transfer restrictions (y=1,n=0) (in \%) & 64.4 & 61.0 & - & 81.5 & - & $* * /(* *)$ \\
Voting restrictions (y=1,n=0) (in \%) & 27.0 & 26.5 & - & 29.6 & - & \\
Staggered board (y=1,n=0) (in \%) & 53.4 & 56.6 & - & 37.0 & - & $* /(*)$ \\
Opting out (y=1,n=0) (in \%) & 16.5 & 16.9 & - & 14.8 & - & \\
\hline
\end{tabular}

\footnotetext{
${ }^{11}$ Such voting caps are legal in Germany and France and it is also possible to issue two classes of equity (even though it is very rare in France, around 3 percent) (Faccio and Lang, 2002).
} 


\subsection{Board of Directors}

The board of directors is an important governance device. Directors are elected by shareholders and their duty is to ensure that the firm is led in the company's best interests. We investigate the overall structure of the board and the characteristics of its directors. In Table III, the general board structure (i.e., one-tier or two-tier, leadership structure, board size, board ownership and compensation) and the board mechanisms (i.e., committees, meetings, and re-election terms) are analyzed. One-tier boards are defined as boards having at least one executive director on the board and two-tier boards are boards without any directors who are executives of the firm at the same time. Table III shows that the structure of the board and also the board mechanisms are quite similar, however, with one important exception: Swiss German boards are more likely to be two-tiered. The boards are structured in the same way as in Germany, i.e., the board of directors is strictly separated from the management boards. In other words, the board of directors consists of no executive directors at all. In contrast, half of the Swiss French boards comprise the chief executive officer (CEO).

As a robustness check, we estimate a Probit model of board structure ( 1 = one-tier board, $0=$ two-tier board) with FRA as its main explanatory variable equaling 1 if the firm is located in the Swiss French part (and 0 if it is located in the Swiss German part) along with sales growth (SGR), board ownership (BOWN), and industry affiliation (INDUSTRY) as control variables. High-growth firms and firms of specific industries (e.g., technology-based firms) may rely on a closer leadership structure with executive directors on their boards. Similarly, higher board ownership suggests an active, eventually executive, function of the board members. The estimates of the analysis and robust standard errors, in parentheses, are reported underneath. The analysis shows that firms in the French-speaking part of Switzerland are significantly more likely to have a onetiered board structure than Swiss German firms (on the 5 percent significance level).

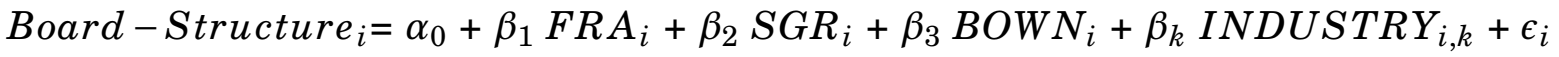

$$
\begin{aligned}
& 0.962 * * \quad 0.631^{*} \quad 1.051 \\
& (0.382) \quad(0.373) \quad(0.690)
\end{aligned}
$$

The second Table IV on boards compares director characteristics, i.e., professional and demographic characteristics of the directors. The analysis shows that the composition of the boards differs as a consequence of language barriers. Directors of French citizenship and directors graduated from a Swiss French university are represented at a higher proportion in corporate boards of the Swiss French part. Similarly, German directors are prevalent in Swiss German boards. Admittedly, the education of a director at a Swiss French university does not entirely imply that they are French-speaking. 
For instance, German-speaking directors might certainly have attended a Swiss French university and vice versa. However, evidence from Switzerland shows that students are attracted by their most familiar universities. Furthermore, board members of Swiss German boards have more external (listed) directorships on average.

Table III: The table documents sample characteristics of board of directors of Swiss German and Swiss French firms. The equality of medians is tested using a Wilcoxon rank sum-test with continuity correction and the equality of means is tested using a Welch Two Sample t-test. Significance at the 1 percent, 5 percent, and 10 percent levels is indicated by ***, **, and *, respectively. "Yes" is denoted y and "no" is denoted $n$.

\begin{tabular}{|c|c|c|c|c|c|c|}
\hline & Sample & \multicolumn{2}{|c|}{ Swiss German } & \multicolumn{2}{|c|}{ Swiss French } & \\
\hline Observations & 163 & \multicolumn{2}{|c|}{136} & \multicolumn{2}{|c|}{27} & \\
\hline in $\%$ & 100 & \multicolumn{2}{|c|}{83} & \multicolumn{2}{|c|}{17} & \\
\hline & Mean & Mean & Median & Mean & Median & $\begin{array}{c}\text { t-test/ } \\
\text { (Wilcoxon-test) }\end{array}$ \\
\hline \multicolumn{7}{|l|}{ Panel A: Board Chracteristics (in \%) } \\
\hline One-tiered boards $(\mathrm{y}=1, \mathrm{n}=0)$ & 52.8 & 49.3 & - & 70.4 & - & $* * /(* *)$ \\
\hline CEO is chairman $(\mathrm{y}=1, \mathrm{n}=0)$ & 15.3 & 14.7 & - & 18.5 & - & \\
\hline CEO is on the board $(\mathrm{y}=1, \mathrm{n}=0)$ & 36.8 & 33.8 & - & 51.9 & - & $* /(*)$ \\
\hline Board size (count) & 6.56 & 6.51 & 6.00 & 6.85 & 6.00 & \\
\hline Board ownership & 13.6 & 13.8 & 3.6 & 12.1 & 3.8 & \\
\hline Board compensation (averages) & 278,695 & 278,496 & 171,600 & 279,741 & 182,500 & \\
\hline \multicolumn{7}{|l|}{ Panel B: Board Workings } \\
\hline Number of committees (count) & 1.96 & 1.98 & 2.00 & 1.89 & 2.00 & \\
\hline $\begin{array}{l}\text { Hours of board meetings (count) } \\
\text { (including committees) }\end{array}$ & 71.46 & 71.57 & 64.00 & 70.92 & 67.00 & \\
\hline Number of board meetings (count) & 6.96 & 6.98 & 6.00 & 6.83 & 6.00 & \\
\hline Age limitation $(\mathrm{y}=1, \mathrm{n}=0)($ in $\%)$ & 45.4 & 46.3 & - & 40.7 & - & \\
\hline Tenure limitation $(\mathrm{y}=1, \mathrm{n}=0)($ in $\%)$ & 3.1 & 3.7 & - & 0.0 & - & $* * /(-)$ \\
\hline Single year election $(\mathrm{y}=1, \mathrm{n}=0)($ in $\%)$ & 21.5 & 16.9 & - & 44.4 & - & $* * /(* * *)$ \\
\hline
\end{tabular}

\subsection{CEO and Firm Characteristics}

The next step in our analysis investigates differences in CEO and firm characteristics. Firstly, debates on corporate governance commonly focus on the CEOs and his decisions, performance or salary. Table V shows that both, CEOs in Swiss French firms and in Swiss German firms exhibit the same features (all CEOs are around 52 years old) and earn very similar amounts on average (CHF $2 \mathrm{M})$.

Secondly, the corporate governance is typically a response to the firm's operational environment and is adopted to the firm's specific situation. Therefore, we examine whether firm characteristics differ from Swiss German firms to Swiss French firms. If they do, those factors might have influenced the findings from the comparisons in corporate governance. The use of the IFRS standard is included in this analysis since stronger accounting standards curb private benefits (see Dyck and Zingales, 2004). However, Table VI 
Table IV: The table presents comparisons of director characteristics between Swiss German and Swiss French firms. The equality of medians is tested using a Wilcoxon rank sum-test with continuity correction and the equality of means is tested using a Welch Two Sample t-test. Significance at the 1 percent, 5 percent, and 10 percent levels is indicated by ***,**, and *, respectively. Per director is denoted p.d.

\begin{tabular}{|c|c|c|c|c|c|c|}
\hline & Sample & \multicolumn{2}{|c|}{ Swiss German } & \multicolumn{2}{|c|}{ Swiss French } & \\
\hline Observations & 163 & \multicolumn{2}{|c|}{136} & \multicolumn{2}{|c|}{27} & \\
\hline in $\%$ & 100 & \multicolumn{2}{|c|}{83} & \multicolumn{2}{|c|}{17} & \\
\hline & Mean & Mean & Median & Mean & Median & $\begin{array}{l}\text { t-test/ } \\
\text { (Wilcoxon-test) }\end{array}$ \\
\hline \multicolumn{7}{|l|}{ Panel A: Director Characteristics (in \%) } \\
\hline Lawyers & 17.9 & 18.0 & 16.7 & 17.3 & 14.3 & \multirow{3}{*}{$* * * /(* * *)$} \\
\hline Swiss French university graduates & 8.8 & 5.0 & 0.0 & 28.3 & 25.0 & \\
\hline Foreign university graduates & 21.9 & 21.8 & 20.0 & 22.2 & 14.3 & \\
\hline Independent directors & 71.9 & 7.3 & 75.0 & 68.7 & 77.8 & \multirow{3}{*}{$-/(*)$} \\
\hline Executives & 13.3 & 12.5 & 0.0 & 16.9 & 16.7 & \\
\hline Family representatives & 7.5 & 7.0 & 0.0 & 9.9 & 0.0 & \\
\hline Shareholder representatives & 8.7 & 9.1 & 0.0 & 6.7 & 0.0 & \multirow[b]{3}{*}{$* * * /(* *)$} \\
\hline Number of mandates (p.d.) & 3.22 & 3.22 & 3.00 & 3.26 & 3.44 & \\
\hline $\begin{array}{l}\text { Number of listed directorships (p.d.) } \\
\text { (counts in SPI firms) }\end{array}$ & 0.42 & 0.45 & 0.40 & 0.26 & 0.25 & \\
\hline \multicolumn{7}{|l|}{ Panel B: Board Demography (in \%) } \\
\hline Women & 4.0 & 4.1 & 0.0 & 3.7 & 0.0 & \multirow{7}{*}{$\begin{array}{c}* * /(-) \\
* * /(* * *)\end{array}$} \\
\hline Foreigners & 26.7 & 26.7 & 20.0 & 26.6 & 22.2 & \\
\hline German & 8.8 & 9.5 & 0.0 & 5.0 & 0.0 & \\
\hline French & 3.0 & 2.2 & 0.0 & 6.8 & 0.0 & \\
\hline Anglo-Saxon & 6.7 & 6.4 & 0.0 & 8.4 & 0.0 & \\
\hline Board's average age (years) & 57.1 & 57.1 & 57.5 & 57.3 & 58.0 & \\
\hline Board's average tenure (years) & 7.8 & 7.8 & 7.0 & 7.9 & 7.6 & \\
\hline
\end{tabular}

Table V: The table presents comparisons of CEO characteristics between Swiss German and Swiss French firms. The equality of medians is tested using a Wilcoxon rank sum-test with continuity correction and the equality of means is tested using a Welch Two Sample t-test. Significance at the 1 percent, 5 percent, and 10 percent levels is indicated by ***, **, and *, respectively. "Yes" is denoted y and "no" is denoted n.

\begin{tabular}{|c|c|c|c|c|c|c|}
\hline & Sample & \multicolumn{2}{|c|}{ Swiss German } & \multicolumn{2}{|c|}{ Swiss French } & \\
\hline Observations & 163 & \multicolumn{2}{|c|}{136} & \multicolumn{2}{|c|}{27} & \\
\hline in $\%$ & 100 & \multicolumn{2}{|c|}{83} & \multicolumn{2}{|c|}{17} & \\
\hline & Mean & Mean & Median & Mean & Median & $\begin{array}{c}\text { t-test/ } \\
\text { (Wilcoxon-test) }\end{array}$ \\
\hline Management size (count) & 6.35 & 6.29 & 6.00 & 6.67 & 6.00 & \\
\hline CEO compensation (in CHF) & $2,048,000$ & $1,991,913$ & $1,077,000$ & $2,325,970$ & 874,000 & \\
\hline CEO ownership (in \%) & 3.4 & 2.8 & 0.0 & 6.5 & 0.0 & \\
\hline CEO age (years) & 52.4 & 52.4 & 52.0 & 52.6 & 52.0 & \\
\hline CEO tenure (years) & 6.5 & 6.1 & 5.0 & 8.6 & 6.0 & \\
\hline
\end{tabular}


shows that also the firms do not differ significantly. In either area, industrial goods and services are the most important industry, but no differences in firm characteristics can be detected at all.

Table VI: The table presents comparisons of firm characteristics between Swiss German and Swiss French firms. The equality of medians is tested using a Wilcoxon rank sum-test with continuity correction and the equality of means is tested using a Welch Two Sample t-test. Significance at the 1 percent, 5 percent, and 10 percent levels is indicated by ***, **, and *, respectively. "Yes" is denoted y and "no" is denoted n.

\begin{tabular}{|c|c|c|c|c|c|c|}
\hline & Sample & \multicolumn{2}{|c|}{ Swiss German } & \multicolumn{3}{|c|}{ Swiss French } \\
\hline Observations & 163 & \multicolumn{2}{|c|}{136} & \multicolumn{2}{|c|}{27} & \\
\hline in $\%$ & 100 & \multicolumn{2}{|c|}{83} & \multicolumn{2}{|c|}{17} & \\
\hline & Mean & Mean & Median & Mean & Median & $\begin{array}{c}\text { t-test/ } \\
\text { (Wilcoxon-test) }\end{array}$ \\
\hline \multicolumn{7}{|l|}{ Panel A: Firm Key Figures } \\
\hline Net annual sales (CHF in Millions) & 4,157 & 3,760 & 505 & 6,159 & 285 & \\
\hline Sales growth (in \%) & 20.8 & 23.5 & 11.1 & 7.2 & 9.5 & \\
\hline Diversification $(\mathrm{y}=1, \mathrm{n}=0)$ & 71.8 & 70.6 & - & 77.8 & - & \\
\hline SMI $(y=1, n=0)$ & 10.4 & 10.3 & - & 11.1 & - & \\
\hline DAR & 48.1 & 48.1 & 48.8 & 48.5 & 50.2 & \\
\hline IFRS standard $(\mathrm{y}=1, \mathrm{n}=0)$ & 76.1 & 75.7 & - & 77.8 & - & \\
\hline \multicolumn{7}{|c|}{ Panel B: Three Most Important Industries } \\
\hline & \multicolumn{3}{|c|}{ Swiss German } & \multicolumn{3}{|c|}{ Swiss French } \\
\hline First industry (in \%) & \multirow{2}{*}{\multicolumn{3}{|c|}{$\begin{array}{l}\text { Industrial goods \& } \\
\text { Health care (15) }\end{array}$}} & \multicolumn{3}{|c|}{ Industrial goods \& services (33) } \\
\hline Second industry (in \%) & & & & \multicolumn{3}{|c|}{ Personal \& household goods (15) } \\
\hline Third industry (in \%) & \multicolumn{3}{|c|}{ Technology (12) } & \multicolumn{3}{|c|}{ Media (15) } \\
\hline
\end{tabular}

\subsection{Firms Established Before 1989}

As a final point of analysis, we compare only firms that were established before 1989, near the end of the cold war in order to capture a feature of this historic period. Furthermore, in 1992, a new Swiss company law and in 1995, the Stock Exchange Act have been introduced. We expect such firms to be more closely related to their cultural basis. The new sample consists of 123 firms which are divided into 101 Swiss German firms and 22 Swiss French firms. Only the variables that indicated a significant difference in the basis sample are re-examined. However, as Table VII depicts, almost all differences remain the same after the sample is reduced to firms established before 1989. So, there are no differences to whether the firm was established before or after the fall of the Berlin Wall.

\section{Conclusions}

Besides legal or historical reasons, corporate governance could be influenced by cultural norms. Switzerland offers an excellent research opportunity since firms are mainly lo- 
Table VII: The table presents comparisons of corporate governance between Swiss German and Swiss French firms established before 1989. The equality of medians is tested using a Wilcoxon rank sumtest with continuity correction and the equality of means is tested using a Welch Two Sample t-test. Significance at the 1 percent, 5 percent, and 10 percent levels is indicated by ${ }^{* * *},{ }^{* *}$, and ${ }^{*}$, respectively. "Yes" is denoted y and "no" is denoted n.

\begin{tabular}{lccc}
\hline & Swiss German & Swiss French & \\
\hline Obs & 101 & 22 & \\
in \% & 82 & 18 & \\
\hline & & & t-test/ \\
& Mean & Mean & (Wilcoxon-test) \\
\hline Swiss French university graduates (in \%) & 5.2 & 30.7 & $* * * /(* * *)$ \\
Executives (in \%) & 11.4 & 14.6 & $-/(*)$ \\
German on board (in \%) & 8.8 & 4.7 & $* /(-)$ \\
French on board (in \%) & 1.9 & 6.0 & $* /(* *)$ \\
One-tiered boards (y=1,n=0) (in \%) & 44.6 & 68.2 & $* * /(* *)$ \\
CEO on the board (y=1,n=0) (in \%) & 29.7 & 45.5 & $* * * /(* *)$ \\
Number of listed directorships p.d. (count) & 0.48 & 27.00 & $* * /(-)$ \\
Tenure limitation (y=1,n=0) (in \%) & 4.0 & 0.0 & $* * /(* *)$ \\
Single year election (y=1,n=0) (in \%) & 15.8 & 40.9 & $* * /(*)$ \\
Transfer restrictions (y=1,n=0) (in \%) & 55.4 & 77.2 & \\
Staggered board (y=1,n=0) (in \%) & 54.4 & 36.4 & \\
Type of the largest shareholder: & & & \\
- private investor (y=1,n=0) (in \%) & 32.7 & 18.2 & \\
- state (y=1,n=0) (in \%) & 1.0 & 0.0 & \\
- industry firm (y=1,n=0) (in \%) & 14.9 & 31.8 & $-/(*)$ \\
U.S. institutional shareholders (in \%) & 2.1 & 0.8 & $* *$ \\
German shareholders (in \%) & 2.8 & 1.4 & $* /(* * *)$ \\
French shareholders (in \%) & 0.1 & 0.9 & \\
\hline
\end{tabular}


cated in two cultural areas: French- and German-speaking Switzerland. Most importantly, both areas share one and the same federal company law. This allows us to isolate potential cultural differences. The results indicate that there are no strong structural differences in the corporate governance between the two regions. Surprisingly, most figures are almost identical. CEO characteristics and firm characteristics show no differences at all. However, there is one strong exception: Swiss German boards are more likely to be two-tiered. The boards are structured in the same way as in Germany, i.e., the board of directors is strictly separated from the management board. In the French area, the probability of an executive being also a board member is higher.

Differences in the composition of the board and the investor base are most probably related to language barriers. The boards in the Swiss French part are composed by directors who have mostly been educated at Swiss French universities. In addition, French citizens are also more prevalent in Swiss French boards. In contrast, German citizens are more frequent in Swiss German boards. This also suggests that the (national) market for directors is segmented into regions. However, these differences have no impact on the overall corporate governance. The ownership structure is almost equal. The only robust difference reveals that individuals are more likely to be the largest investors in Swiss German firms. Concerning takeover defenses, the two regions have distinct favorite devices. In the German part, staggered boards are more frequent, while in the French part, the transfer restriction of registered shares ("Vinkulierung") is an important feature. Furthermore, our results are robust to the exclusion of firms that were established after 1989.

Most factors in corporate governance show no differences. Nevertheless, some important factors, notably the overall board structure is related to the cultural region, because the legal system requires no specific structure. Hence, the legal system or the nation's overall identity might have shaped most of Switzerland's corporate governance. Switzerland is often referred to as a country forged by the will of the people ("Willensnation"). However, our analysis is restricted to listed firms that comply with national and international corporate governance standards. We don't know whether cultural differences are more distinctive in non-listed firms. 


\section{References}

Aguilera, R. V. and G. Jackson, "The Cross-National Diversity of Corporate Governance: Dimensions and Determinants," Academy of Management Review, 2003, 28 (3), $447-465$.

Bebchuk, L. A. and M. J. Roe, "A Theory of Path Dependence in Corporate Ownership and Governance," Stanford Law Review, 1999, 52 (1), 127-170.

Boubraki, N., Y. Bozec, C. Laurin, and S. Rousseau, "Incorporation Law, Ownership Structure, and Firm Value: Evidence from Canada," Journal of Empirical Legal Studies, 2011, 8 (2), 358-383.

Bozec, Y., S. Rousseau, and C. Laurin, "Law of Incorporation and Firm Ownership Structure: The Law and Finance Theory Revisited," International Review of Law and Economics, 2008, 28 (2), 140-149.

Brost, M., "Was ist an Deutschland so verlockend?," Die Zeit, 2005, April 28, No. 18.

Djankov, S., R. La Porta, F. Lopez de Silanes, and A. Shleifer, "The Law and Economics of Self-Dealing," Journal of Financial Economics, 2008, 88 (3), 430-465.

Dubs, D. and C. Wieser, "Vinkulierung - Klärung tut not," Finanz und Wirtschaft, 2009, July 11.

Dyck, A. and L. Zingales, "Private Benefits of Control: An International Comparison," The Journal of Finance, 2004, 59 (2), 537-600.

Faccio, M. and L. H. P. Lang, "The Ultimate Ownership of Western European Corporations," Journal of Financial Economics, 2002, 65 (3), 365-395.

Hopt, K. J. and P. C. Leyens, "Board Models in Europe-Recent Developments of Internal Corporate Governance Structures in Germany, the United Kingdom, France, and Italy," European Company and Financial Law Review, 2004, 1 (2), 135-168.

La Porta, R., F. Lopez de Silanes, A. Shleifer, and R. Vishny, "Law and Finance," The Journal of Political Economy, 1998, 106 (6), 1113-1155.

_, , , , and _ , "Investor Protection and Corporate Governance," Journal of Financial Economics, 2000, 58 (1-2), 3-27.

Licht, A. N., C. Goldschmidt, and S. H. Schwartz, "Culture, Law, and Corporate Governance," International Review of Law and Economics, 2005, 25 (2), 229-255.

SIX Exchange, “Directive on Information Relating to Corporate Governance,” 2008. 
The Economist, "To the Barricades - A Wave of Cross-Border Mergers in Europe Provokes a Nationalist Backlash,” 2006, March 2.

Wymeersch, E., "A Status Report on Corporate Governance Rules and Practices in Some Continental European States," in K. J. Hopt, H. Kanda, M. J. Roe, E. Wymeersch, and S. Prigge, eds., Comparative Corporate Governance. The State of the Art and Emerging Research, Oxford: Clarendon Press, 1998, pp. 1046-1199. 